\title{
Evaluering av inflammatoriske mediatorer i diagnostikk av alvorlige neonatale infeksjoner
}

\author{
H. Døllner ${ }^{1}$, H. Johnsen ${ }^{2}$, L. Vatten ${ }^{3}$, K.J. Arntzen ${ }^{4}$ og R. Austgulen ${ }^{4}$ \\ 1. Barneklinikken, Regionsykehuset $i$ Trondheim \\ 2. Avdeling for klinisk kjemi, Regionsykehuset i Trondheim \\ 3. Institutt for samfunnmedisinske fag, Norges teknisk-naturvitenskapelige universitet, Trondheim \\ 4. Institutt for kreftforskning og molekylaer biologi, Norges teknisk-naturvitenskapelige universitet, Trondheim \\ Støttet av: Norges Forskningsråd, Nasjonalforeningen for folkehelsen og Nyfødtfondet ved Regionsykehuset i Trondheim \\ Korrespondanse til: Henrik Døllner, Barneklinikken, Regionsykehuset i Trondheim, 7006 Trondheim \\ Telefon: 73998143 Telefax: 73997322
}

\begin{abstract}
SAMMENDRAG
Formål: $\AA$ studere C-reaktivt protein (CRP), interleukin-6 (IL-6), tumor nekrose faktor reseptor (TNFR) p55 og p75 og adhesjonsmolekylene ICAM-1 og E-selectin som parametre for alvorlig bakteriell infeksjon hos nyfødte barn.

Studie design: Konsentrasjon av de inflammatoriske mediatorer ble bestemt i serum ved innleggelse hos 165 nyfødte barn med mistanke om alvorlig bakteriell infeksjon. Vi analyserte verdien av mediatorene enkeltvis eller i kombinasjon til å predikere alvorlig neonatal infeksjon med multippel logistisk regresjon, receiveroperator characteristic kurver og beregning av sensitivitet og spesifisitet.

Resultater: Tjuefire barn med sepsis, klinisk sepsis og pneumoni hadde høyere serum konsentrasjon av alle seks inflammatoriske mediatorer enn barn uten infeksjon (alle $p<0,05$ ). Logaritmen til CRP og logaritmen til IL-6 predikerte uavhengig infeksjon ( $p<0,001$, resp. $p=0,03$ ). Ingen av de øvrige fire mediatorer ga ytterligere bidrag til infeksjonsdiagnosen. En kombinert parameter bestående av CRP $\geq 10 \mathrm{mg} / \mathrm{log} / \mathrm{eller}$ IL-6 $>50 \mathrm{pg} / \mathrm{ml}$ ga en sensitivitet på 96\% (95\% CI: 88-100\%), en spesifisitet på 74\% (95\% CI: 65-83\%), en negativ prediktiv verdi på 99\% (95\% CI: 96-100\%) og en positiv prediktiv verdi på 49\% (95\% CI: 35-63\%).

Konklusjon: IL-6 i kombinasjon med CRP synes å være en verdifull parameter ved utredning av nyfødte barn ved mistanke om alvorlig bakteriell infeksjon.
\end{abstract}

Døllner H, Johnsen H, Vatten L, Arntzen KJ, Austgulen R. The value of inflammatory mediators in the diagnosis of severe neonatal infections. Nor J Epidemiol 1997; 7 (1): $73-78$.

\section{ENGLISH SUMMARY}

Objective: To study C-reactive protein (CRP), interleukin-6 (IL-6), soluble tumor necrosis factor receptors (TNFR) p55 and p75 and the adhesion molecules ICAM-1 and E-selectin in the early diagnosis of neonatal sepsis.

Study design: Blood samples were collected at admittance from 165 neonates who were suspected to have a severe bacterial infection and serum concentrations of the six inflammatory mediators were determined. We analysed the mediators, either isolated or in combination, as diagnostic parameters by multiple logistic regression, receiver-operator characteristic plots and predictive value theory (sensitivity and specificity).

Results: Twentyfour neonates with sepsis, clinical sepsis and pneumonia had significantly raised serum levels of all six mediators compared to noninfected neonates (all $p<0.05$ ). The logaritm of CRP and the logaritm of IL- 6 yielded independent contributions to the diagnosis of infection $(p<0.001$ resp. $p=0.03)$. No other mediator made any further contribution to the diagnosis. A combined parameter of CRP $\geq 10 \mathrm{mg} / \mathrm{l}$ and/or IL- $6>$ $50 \mathrm{pg} / \mathrm{ml}$ yielded a sensitivity of $96 \%$ (95\% CI: $88-100 \%$ ), a specificity of $74 \%$ (95\% CI: $65-83 \%)$, a negative predictive value of $99 \%(95 \%$ CI: $96-100 \%)$ and a positive predictive value of $49 \%$ (95\% CI: $35-63 \%)$.

Conclusion: IL-6 in combination with CRP may constitute a valuable parameter in the early diagnosis of severe neonatal infections. 


\section{INNLEDNING}

Bakterielle infeksjoner som sepsis og pneumoni i nyfødtperioden er alvorlige tilstander med høy morbiditet og mortalitet (1). Diagnostikk av infeksjoner hos nyfødte er vanskelig fordi de kliniske symptomer og funn er uspesifikke. Vanlige infeksjonsparametre som senkningsreaksjon (SR) og antall hvite blodlegemer gir bare begrenset diagnostisk informasjon hos nyfødte (2). I utredningen av nyfødte med mistenkt infeksjon anvendes idag først og fremst akutt fase reaktanten C-reaktivt protein (CRP). I nyfødtperioden har CRP høy spesifisitet, men begrenset sensitivitet $\mathrm{i}$ det tidlige stadium av infeksjon $(3,4)$.

På grunn av de diagnostiske problemer og de alvorlige konsekvenser det kan ha å overse en bakteriell infeksjon hos et nyfødt barn, er det vanlig å behandle med bredspektrede antibiotika før sikker diagnose er stilt. Det er imidlertid vist at bare $5-10 \%$ av nyfødte som behandles med antibiotika på mistanke om infeksjon faktisk har en infeksjon $(5,6)$. Den økende bakterielle resistens på mange intensivavdelinger kan ha en sammenheng med det overforbruk av bredspektrede antibiotika som finner sted (7).

Tumor nekrose faktor (TNF) og interleukin-6 (IL6) er proinflammatoriske cytokiner som er involvert i immunforsvaret mot bakterier og sopp $(8,9)$. Enkelte studier har antydet at IL-6 kan være en god tidlig parameter ved sepsis hos nyfødte $(10,11)$. TNF medierer sin virkning via to membranbundne reseptorer, $\mathrm{p} 55 \mathrm{og}$ p75. Disse to reseptorer kan spaltes fra celleoverflaten og eksisterer som løselige former i serum (12). Hos voksne og barn er det funnet økte serumnivåer av løselige TNF-reseptorer ved sepsis $(13,14)$. Forskjellige adhesjonsmolekyler lokalisert på endothel og leukocytter er involvert i den tidlige inflammatoriske respons ved infeksjon og medvirker bl.a. til adhesjon og migrasjon av leukocytter (15). Celleaktivering kan føre til avspaltning av adhesjonsmolekyler på endotelet til løselige adhesjonsmolekyler i serum (15). Økte serumnivåer av ICAM-1 (intercellular adhesion molecule-1) og E-selectin er funnet hos voksne ved en rekke patologiske tilstander, bl.a. ved sepsis (16).

Formålet med denne studien var å evaluere betydningen av inflammatoriske mediatorer (CRP, IL-6, løselige TNF-reseptorer (p55, p75) og løselige adhesjonsmolekyler (ICAM-1, E-selectin)) som tidlige parametre ved alvorlig bakteriell infeksjon hos nyfødte barn.

\section{MATERIALE OG METODER}

\section{Studiepopulasjon}

Etthundreogsekstifem nyfødte barn med mistenkt bakteriell infeksjon fortløpende innlagt på neonatalseksjonen, Barneklinikken, Regionsykehuset i Trondheim ble inkludert i studien. Kliniske tegn og symptomer på infeksjon ble registrert og delt i seks kategorier: 1) blekhet og gulsott, 2) slapphet, apnø, bradykardi, irritabilitet og kramper, 3) takypnø og dyspnø, 4) hypotensjon, takykardi og dårlig perifer sirkulasjon, 5) oppkast og oppblåst mage og 6) feber og ustabil temperatur. Blodprøve ble tatt ved innleggelse, sentrifugert og oppbevart ved $-20^{\circ} \mathrm{C}$ inntil konsentrasjonsbestemmelse av inflammatoriske mediatorer ble foretatt. Alle barn ble utredet med blodkultur, bestemmelse av antall hvite blodlegemer, I/T-ratio (ratio mellom antall umodne og totalt antall neutrofile granulocytter) og CRP. CRP ble bestemt daglig hos de fleste barn. Den maksimale CRP-verdi ble definert som den høyeste verdi i første leveuke og brukt til å klassifisere barna.

\section{Analysemetoder}

CRP ble bestemt immunoturbidometrisk (17). CRP-verdier $\geq 10 \mathrm{mg} / \mathrm{l}$ ble definert som patologisk forhøyet (4).

IL-6 ble bestemt ved hjelp av et bioassay $(18,19)$. Spesifisiteten av den bestemte IL-6 aktivitet ble testet med monoklonale antistoffer mot IL-6 (Genzyme, Cambridge, GA).

Nivåer av løselig TNFR p55 og p75 ble bestemt med ELISA-assays utviklet ved Institutt for kreftforskning og molekylær biologi (20).

Kommersielle ELISA-assays ble anvendt til bestemmelse av nivåer av løselig ICAM-1 og E-selectin (Parameter, British Bio-technology, Abingdon, UK).

\section{Klassifikasjon av de nyfodte barn}

Barna ble inndelt retrospektivt i 3 grupper på bakgrunn av resultatene av blodkultur, I/T-ratio ved innleggelse $(>0,20)$, maksimal CRP-verdi i løpet av første leveuke $(\geq 10 \mathrm{mg} / \mathrm{l})$, kliniske tegn og symptomer samt røntgenfunn (Tabell 1). Gruppe 1 inkluderte barn med infeksjon og Gruppe 2 barn med mulig infeksjon. Kontrollgruppen bestod av barn hvor det kliniske forløp og utredning ikke ga holdepunkt for infeksjon.

\section{Statistiske analyser}

Forskjeller mellom konsentrasjonen av mediatorer i de forskjellige grupper ble testet med ikkeparametriske tester (Kruskall-Wallis one-way analysis of variance og Mann-Whitney U test). P-verdier lavere enn 0,05 ble ansett som statistisk signifikante. $\mathrm{Vi}$ analyserte verdien av inflammatoriske mediatorer som infeksjonsparametre hos nyfødte barn ved hjelp av 1: multippel logistisk regresjon, 2: receiveroperator characteristic (ROC) kurver og 3: ved beregning av sensitivitet, spesifisitet og positiv og negativ prediktiv verdi. Hver enkel mediators evne til uavhengig å predikere infeksjonsdiagnosen ble vurdert med multippel logistisk regresjon (21). ROCkurver avbilder sensitivitet (sann positiv rate) mot 1 spesifisitet (falsk positiv rate) for en rekke potensielle 
grenseverdier av en kontinuerlig parameter (22). Den optimale grenseverdi for hver enkelt mediator ble bestemt som den verdi som ga høyest sensitivitet $o g$ spesifisitet (på ROC-kurven er det punktet lengst oppe mot venstre hjørne).

\section{RESULTATER}

\section{Populasjonen}

Tjuefire barn hadde infeksjon og ble inkludert $\mathrm{i}$ Gruppe 1. Seks hadde sepsis (Gruppe 1A), 10 hadde klinisk sepsis (Gruppe 1B) og åtte hadde pneumoni (Gruppe 1C) (Tabell 1). Atten barn hadde en mulig infeksjon og ble inkludert i Gruppe 2 (Tabell 1). Ialt 97 barn med negativ utredning ble inkludert i Gruppe 3 (kontrollgruppe, Tabell 1). Tjueseks barn kunne ikke klassifiseres mhp. infeksjon/ikke infeksjon, disse ble ekskludert fra videre analyser. Barnas gestasjons- alder, fødselsvekt og postnatal alder ved innleggelsen framgår av Tabell 2.

Tabell 2. Antall barn i hver studiegruppe, gestasjonsalder, fødselsvekt og postnatal alder.

\begin{tabular}{lccc}
\hline & Gruppe 1 & Gruppe 2 & Kontrollgruppe \\
\hline $\mathrm{n}$ & 24 & 18 & 97 \\
$\begin{array}{l}\text { Gestasjons- } \\
\text { alder (uker) }\end{array}$ & $37,2 \pm 4,4^{\mathrm{a}}$ & $36,7 \pm 4,7^{\mathrm{a}}$ & $34,1 \pm 4,0$ \\
Fødselsvekt (g) & $3116 \pm 1053^{\mathrm{a}}$ & $3061 \pm 1215^{\mathrm{a}}$ & $2240 \pm 828$ \\
Postnatal alder:* & & & \\
$<1$ døgn & 14 & 9 & 83 \\
1-2 døgn & 3 & 3 & 10 \\
$2-4$ døgn & 5 & 6 & 2 \\
\hline
\end{tabular}

Gestasjonsalder og fødselsvekt er angitt som mean ÒSD

${ }^{a} p<0,05$, sammenlignet med kontroll gruppen

* Ved innleggelse på neonatalseksjonen

Tabell 1. Kriterier for klassifikasjon av nyfødte barn.

\begin{tabular}{|c|c|c|c|c|}
\hline \multicolumn{3}{|c|}{ Gruppe 1: Infeksjon } & \multirow{2}{*}{$\begin{array}{l}\text { Gruppe 2: } \\
\text { Mulig } \\
\text { infeksjon }\end{array}$} & \multirow{2}{*}{$\begin{array}{l}\text { Kontrollgruppe: } \\
\text { Ingen } \\
\text { infeksjon }\end{array}$} \\
\hline $\begin{array}{l}\text { Gruppe 1A } \\
\text { Sepsis }\end{array}$ & $\begin{array}{l}\text { Gruppe 1B } \\
\text { Klinisk sepsis }\end{array}$ & $\begin{array}{l}\text { Gruppe 1C } \\
\text { Pneumoni }\end{array}$ & & \\
\hline $\begin{array}{l}\text { 1. Positiv blod- } \\
\text { spinalvæske } \\
\text { kultur } \\
\text { 2. Kliniske tegn } \\
\text { forenlig med } \\
\text { sepsis/ } \\
\text { meningitt }\end{array}$ & $\begin{array}{l}\text { 1. Negativ blodkultur } \\
\text { 2. Minst } 1 \text { symptom fra } \\
\text { minst } 3 \text { kategorier av } \\
\text { kliniske symptomer } \\
\text { 3. Økt I/T-ratio }(>0,20) \\
\text { 4. Økt maksimal CRP } \\
\quad(\geq 10 \mathrm{mg} / \mathrm{l})\end{array}$ & $\begin{array}{l}\text { 1. Negativ blodkultur } \\
\text { 2. Respiratoriske } \\
\text { symptomer } \\
\text { 3. Økt I/T-ratio }(>0,20) \\
\text { 4. Økt maksimal CRP } \\
\quad(\geq 10 \mathrm{mg} / \mathrm{l}) \\
\text { 5. Røntgenologiske tegn } \\
\text { på pneumoni }\end{array}$ & $\begin{array}{l}\text { 1. Negativ blodkultur } \\
\text { 2. Minst } 1 \text { symptom fra } \\
\text { minst } 2 \text { kategorier av } \\
\text { kliniske symptomer } \\
\text { 3. Økt I/T-ratio }(>0,20) \\
\text { eller } \\
\text { 4. Økt maksimal CRP } \\
(\geq 10 \mathrm{mg} / \mathrm{l})\end{array}$ & $\begin{array}{l}\text { Nyfødte } \\
\text { mistenkt for } \\
\text { infeksjon, men } \\
\text { der utredning og } \\
\text { forløp ikke ga } \\
\text { holdepunkt for } \\
\text { infeksjon. }\end{array}$ \\
\hline
\end{tabular}

I/T-ratio: ratio mellom antall umodne og total antall granulocytter.

CRP: $\quad$ C-reaktivt protein.

\section{Konsentrasjon av inflammatoriske mediatorer}

Serumkonsentrasjonen av CRP, IL-6, løselig ICAM1, løselig E-selectin og løselig TNFR p55 og p75 ved innleggelse på avdelingen er vist i Tabell 3. For alle mediatorer fant vi at konsentrasjonen var signifikant høyere hos barn med infeksjon sammenlignet med barn uten infeksjon.

\section{Diagnostikk av infeksjon hos nyfodte barn i forste leveuke}

ROC-kurver for CRP, IL-6, løselig ICAM-1, løselig E-selectin, og løselig TNFR p55 og p75 viste at CRP og IL-6 har de beste kombinasjoner av sensitivitet og spesifisitet (Figur 1).

De prediktive verdier av hver mediator ble beregnet ved å betrakte nyfødte med infeksjon (sepsis, klinisk sepsis og pneumoni, Gruppe 1) som «gull- standard» og nyfødte i Gruppe 3 som «kontroller». Eselectin og IL-6 var de mest sensitive parametre, mens CRP var den mest spesifikke (Tabell 4).

Multippel logistisk regresjon viste at logaritmen til CRP uavhengig predikerte infeksjon $i$ en modell med infeksjon som avhengig variabel og alle seks inflammatoriske mediatorer som uavhengige variabler $(p<$ 0,001). Logaritmen til IL-6 predikerte også infeksjon uavhengig $(p=0,03)$, mens ingen av de øvrige mediatorer gav ytterligere diagnostisk informasjon $\mathrm{i}$ denne modell.

Basert på resultatene av multippel logistisk regresjon og ROC-kurvene, laget vi en kombinert parameter bestående av CRP $\geq 10 \mathrm{mg} / \mathrm{log} / \mathrm{eller} \mathrm{IL}-6>50$ $\mathrm{pg} / \mathrm{ml}$. Denne kombinerte parameter gav en sensitivitet på 96\% (95\% CI: $88-100 \%)$, en spesifisitet på $74 \%$ (95\% CI: $65-83 \%)$, en negativ prediktiv verdi på 99\% (95\% CI: $96-100 \%)$ og en positiv prediktiv verdi på 49\% (95\% CI: 35-63\%). 


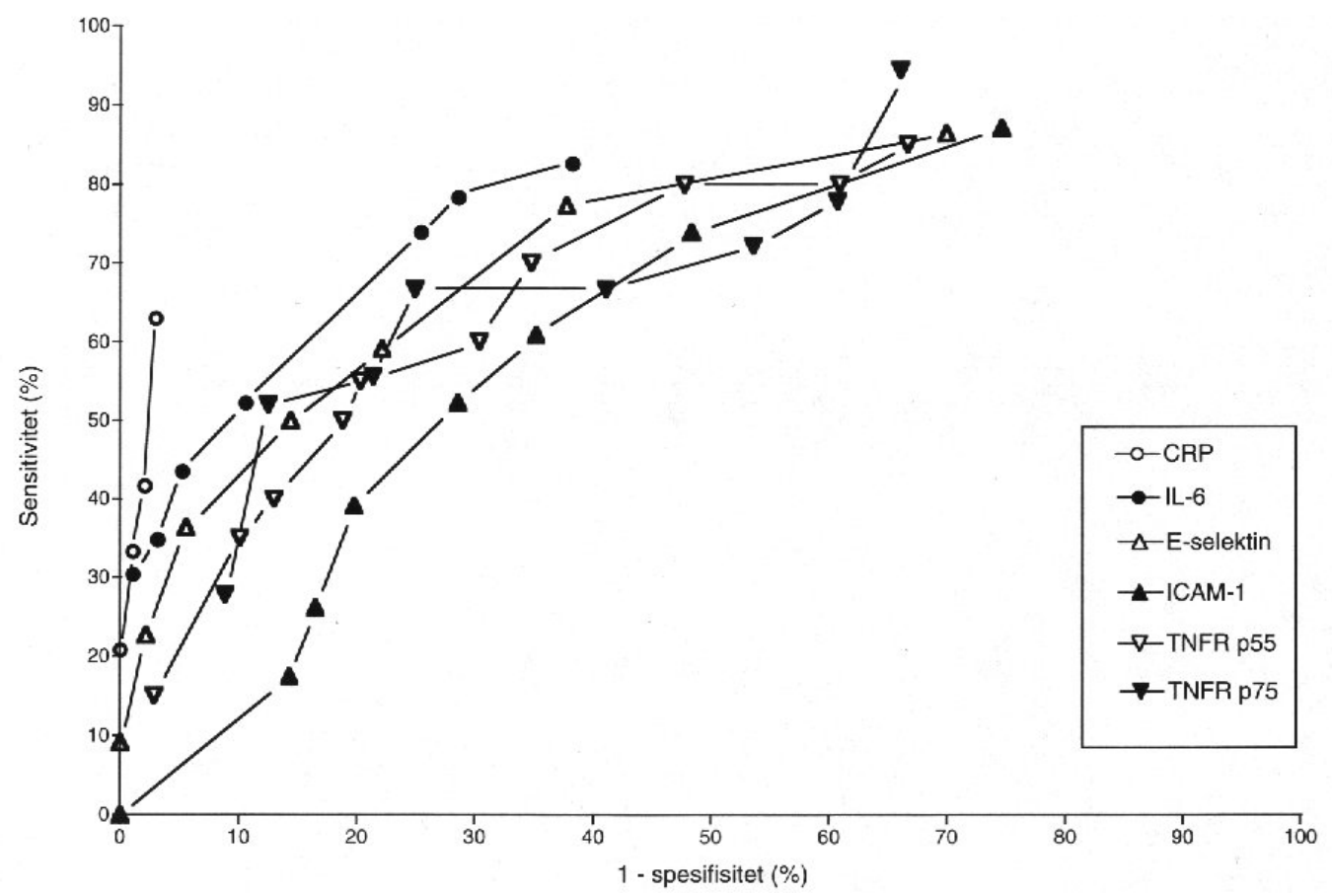

Figur 1. ROC-kurver for CRP (C-reaktivt protein), IL-6 (interleukin-6), løselig ICAM-1 (intercellulært adhesjonsmolekyl-1), løselig E-selectin og løselig TNFR (tumor nekrose faktor reseptor) p55 og p75.

Tabell 3. Konsentrasjon av CRP (C-reaktivt protein), IL-6 (interleukin-6), ICAM-1 (intercellullært adhesjonsmolekyl-1), Eselectin og tumor nekrose faktor reseptor (TNFR) p55 og p75 i serum ved innleggelsen på neonatalseksjonen, Barneklinikken.

\begin{tabular}{|c|c|c|c|c|c|c|c|c|c|}
\hline & \multicolumn{3}{|c|}{ Gruppe 1: Infeksjon } & \multicolumn{3}{|c|}{ Gruppe 2: Mulig infeksjon } & \multicolumn{3}{|c|}{ Kontrollgruppe: ingen infeksjon } \\
\hline & $\mathrm{n}$ & median & IQR* & $\mathrm{n}$ & median & IQR* & $\mathrm{n}$ & median & IQR* \\
\hline CRP (mg/l) & 24 & $13,0^{\mathrm{a}}$ & $6,0-25,8$ & 17 & $7,0^{\mathrm{a}}$ & $0-16,5$ & 94 & 0 & 0 \\
\hline IL-6 (pg/ml) & 23 & $164,0^{\mathrm{a}}$ & $22,2-1830,0$ & 17 & $17,6^{\mathrm{c}}$ & $11,3-306,0$ & 94 & 0 & $0-35,0$ \\
\hline ICAM-1 (ng/ml) & 23 & $357,4^{d}$ & $249,0-459,6$ & 17 & $413,0^{\mathrm{b}}$ & $322,0-500,0$ & 91 & 244,0 & $196,2-376,2$ \\
\hline E-sel (ng/ml) & 22 & $151,7^{\mathrm{b}}$ & $107,2-195,1$ & 17 & $119,6^{\mathrm{d}}$ & $84,9-197,7$ & 90 & 91,3 & $69,5-118,4$ \\
\hline p55 (ng/ml) & 20 & $10,0^{\mathrm{c}}$ & $7,8-12,7$ & 11 & 7,0 & $4,4-9,5$ & 69 & 7,5 & $6,0-8,8$ \\
\hline p75 (ng/ml) & 18 & $8,9^{\mathrm{c}}$ & $6,1-10,3$ & 12 & $7,6^{\mathrm{d}}$ & $6,3-8,6$ & 56 & 6,7 & $5,2-7,6$ \\
\hline
\end{tabular}

* inter kvartil range

${ }^{a} p<0,0001$ sammenlignet med kontrollgruppen

${ }^{\mathrm{b}} p<0,001$ sammenlignet med kontrollgruppen

c $p<0,01$ sammenlignet med kontrollgruppen

d $p<0,05$ sammenlignet med kontrollgruppen

Tabell 4. Prediktive verdier for CRP (C-reaktivt protein), IL-6 (interleukin-6), tumor nekrose faktor reseptor (TNFR) p55 og p75, E-selectin og ICAM-1 (intercellulært adhesjonsmolekyl1) som parametre for infeksjon hos nyfødte barn.

\begin{tabular}{lcccccc}
\hline & CRP & IL-6 & TNFR p55 & TNFR p75 & E-selectin & ICAM-1 \\
\hline Grenseverdi $^{1}$ & $10 \mathrm{mg} / 1$ & $20 \mathrm{pg} / \mathrm{ml}$ & $8 \mathrm{ng} / \mathrm{ml}$ & $7,5 \mathrm{ng} / \mathrm{ml}$ & $100 \mathrm{ng} / \mathrm{ml}$ & $300 \mathrm{ng} / \mathrm{ml}$ \\
Sensitivitet & $63 \%$ & $78 \%$ & $70 \%$ & $67 \%$ & $77 \%$ & $61 \%$ \\
Spesifisitet $^{2}$ & $97 \%$ & $71 \%$ & $65 \%$ & $75 \%$ & $62 \%$ & $65 \%$ \\
N.P.V. $^{2}$ & $91 \%$ & $93 \%$ & $88 \%$ & $88 \%$ & $92 \%$ & $87 \%$ \\
P.P.V. $^{2}$ & $83 \%$ & $40 \%$ & $37 \%$ & $37 \%$ & $33 \%$ & $30 \%$ \\
\hline
\end{tabular}

${ }^{1}$ Den verdi av mediatoren som gir høyeste sensitivitet $o g$ spesifisitet.

${ }^{2}$ N.P.V., Negativ prediktiv verdi; P.P.V., Positiv prediktiv verdi. 


\section{DISKUSJON}

Det er viktig å påvise bakteriell infeksjon hos nyfødte på et tidlig tidspunkt. Samtidig er det viktig å unngå overbehandling med antibiotika av barn uten infeksjon. Resultatene i denne studien viser at en kombinasjon av CRP og IL-6 kan være en sensitiv parameter for å påvise alvorlig infeksjon hos nyfødte. Denne konklusjon er i overensstemmelse med funn gjort av Buck (10). IL-6 og CRP i kombinasjon er bedre enn IL-6, CRP, TNFR p55 og p75, ICAM-1 og E-selectin anvendt enkeltvis. CRP er den mest spesifikke parameter, men CRP har en lav sensitivitet i den tidlige fase av infeksjonen. Tilsvarende observasjoner er gjort av andre $(3,4)$. IL-6 er tidligere vist å stige raskt ved bakteriell infeksjon hos voksne (23), og IL-6 induserer CRP i den såkalte akutt fase respons $(8,9)$. Våre resultater viser at sensitiviteten øker når IL-6 kombineres med CRP, hvilket betyr at IL-6 og CRP til en viss grad diagnostiserer forskjellige individer. Den kombinerte IL-6/CRP parameter har imidlertid en moderat spesifisitet på $73 \%$. CRP har en negativ prediktiv verdi på $91 \%$, denne øker til $99 \%$ når CRP kombineres med IL-6. Høy negativ prediktiv verdi innebærer at klinikeren kan avvente start av antibiotikabehandling uten å ta unødige sjanser når både CRP og IL-6 er lave.

Vi har anvendt et bioassay til bestemmelse av IL6. Dette bioassay er upraktisk i klinisk arbeid fordi det tar lang tid å utføre. Det finnes imidlertid kommersielle IL-6 ELISA-assays som kan gi et svar på få timer. Nye studier bør gjennomføres for å etablere referanseverdier for IL-6 hos nyfødte med bruk av ELISA assays.

Vi konkluderer at IL-6 i kombinasjon med CRP kan være en aktuell parameter for å høyne presisjonen ved utredning av nyfødte barn ved mistanke om alvorlig infeksjon.

\section{REFERANSER}

1. Klein JO, Marcy SM. Bacterial sepsis and meningitis. In: Remington JS, Klein JO, eds. Infectious diseases of the fetus and newborn infant. Philadelphia: WB Saunders Company, 1995: 835-90.

2. Powell KR, Marcy SM. Laboratory aids for diagnosis of neonatal sepsis. In: Remington JS, Klein JO, eds. Infectious diseases of the fetus and newborn infant. Philadelphia: WB Saunders Company, 1995: 1223-40.

3. Wasunna A, Whitelaw A, Gallimore R, Hawkins PN and Pepys MB. C-reactive protein and bacterial infection in preterm infants. Eur J Pediatr 1990; 149: 424-47.

4. Mathers NJ, Pohlandt F. Diagnostic audit of C-reactive protein in neonatal infection. Eur J Pediatr 1987; 146: $147-51$.

5. Philip AGS, Hewith JR. Early diagnosis of neonatal sepsis. Pediatrics 1980; 65: 1036-41.

6. Gerdes JS, Polin RA. Sepsis screen in neonates with evaluation of plasma fibronectin. Pediatr Infect Dis J 1987; 6: 443-46.

7. Neu HC. The crisis in antibiotic resistence. Science 1992; 257: 1064-73.

8. Emery P, Salmon M. The immune response 2: systemic mediators of inflammation. Br J Hosp Med 1991; 45: 164-8.

9. Kishimoto T. The biology of interleukin 6. Blood 1989; 74: 1-10.

10. Buck C, Bundschu J, Gallati H, Bartmann P, Pohlandt F. Interleukin-6: A sensitive parameter for early diagnosis of neonatal bacterial infection. Pediatrics 1994; 93: 54-8.

11. Harris $\mathrm{CH}$, Costarino AT Jr, Sullivan JS et al. Cytokine elevations in critically ill infants with sepsis and necrotising enterocolitis. J Pediatr 1994; 124: 105-11.

12. Olsson I, Gatanaga U, Gullberg M, Lantz M, Granger A. Tumour necrosis factor (TNF) binding proteins (soluble TNF receptor forms) with possible roles in inflammation and malignancy. Eur Cytokine Netw 1993; 4: $169-180$.

13. van der Poll T, Jansen J, van Leenen D et al. Release of soluble receptors for tumor necrosis factor in clinical sepsis and experimental endotoxemia. J Infect Dis 1993; 168: 955-60.

14. Girardin E, Roux-Lombard P, Grau GE, Suter P, Gallati H, The J5 Study Group, Dayer JM. Imbalance between tumour necrosis factor-alpha and soluble TNF receptor concentrations in severe meningococcaemia. Immunology 1992; 76: 20-23.

15. Springer TA. Adhesion receptors of the immune system. Nature 1990; 346: 425-34.

16. Gearing AJH, Newman W. Circulating adhesion molecules in disease. Immunol Today 1993; 14: 506-12. 
17. Byrjalsen I, Ingwersen SH. Immunoturbidimetry of serum C-reactive protein in low concentration of polyethylene glycol. Ann Clin Biochem 1985; 22: 269-72.

18. Aarden LA, De Groot ER, Schaap OL, Lansdorp PM. Production of hybridoma growth factor by human monocytes. Eur J Immunol 1987; 17: 1411-6.

19. Mosmann TR. Rapid colorimetric assay for cellular growth and survival: application to proliferation and cytotoxicity assays. J Immunol 1986; 136: 2348-57.

20. Liabakk NB, Sundan A, Lien E, Laegreid A, Bombara MP, Ranges G, Espevik T. The release of soluble p55 TNF receptor from U937 cells studied by a new p55 immunoassay. J Immunol Methods 1993; 163: 145-154.

21. Altman DG. In: Practical statistics for medical research. London: Chapman and Hall. 199i: 351-8.

22. Zweig MH, Campbell G. Receiver-operating characteristic (ROC) plots: A fundamental evaluation tool in clinical medicine. Clin Chem 1993; 39: 561-77.

23. Waage A, Brandtzaeg P, Halstensen A, Kierulf P, Espevik T. The complex pattern of cytokines in serum from patients with meningococcal septic shock. $J$ Exp Med 1989; 169: 133-8. 